\title{
Catalityc removal of nitrogen oxide from combustion gases
}

\author{
Wiesława Ćwikła-Bundyra \\ University of Marie Curie-Skłodowska, Faculty of Chemistry, pl. Marie Curie-Skłodowska 3, 20-031 Lublin, Poland, \\ e-mail: cwikla@hermes.umcs.lublin.pl
}

\begin{abstract}
Nitrogen oxide conversion to nitrogen over $\mathrm{Pt} / \mathrm{Al}_{2} \mathrm{O}_{3}, \mathrm{Pd} / \mathrm{Al}_{2} \mathrm{O}_{3}, \mathrm{Rh} / \mathrm{Al}_{2} \mathrm{O}_{3}$ catalysts was investigated. The results of the catalytic activity investigations, with the iso-x method, showed that NO reduction by methane occurs at a reasonable rate at the temperature range $200-500^{\circ} \mathrm{C}$. Alumina-supported $\mathrm{Pd}, \mathrm{Pt}$ and $\mathrm{Rh}$ catalysts have been compared for the selective reduction of $\mathrm{NO}$ to $\mathrm{N}_{2}$. All the catalysts showed good activity in $\mathrm{NO}$ reduction by methane, giving around $80-90 \% \mathrm{~N}_{2}$ production. At moderate temperatures $\mathrm{Pt}$ is the most active catalyst for the removal of NO.
\end{abstract}

Keywords: : catalytic reduction of NO by methane, Platinum group metals catalysts.

Presented at VII Conference Wasteless Technologies and Waste Management in Chemical Industry and Agriculture, Międzyzdroje, 12 - 15 June, 2007.

\section{INTRODUCTION}

Nitrogen oxide is a major atmospheric pollutant. It is emitted primarily from transportation, industrial sources resulting from the combustion of fossil fuels in stationary sources such as industrial boilers, power plants, waste incinerators, engines and gas turbines or from the decomposition of a large number of organic products by light or micro-organisms. NO has the ability to generate secondary contaminants through its interaction with other primary pollutants like carbonyl, alcohol radicals. For these reasons, it contributes largely to a variety of environmental problems ${ }^{1-3}$. Nitrogen oxide plays a major role in the photochemistry of the troposphere, the stratosphere and reacts with photochemical pollutants such as ozone, formaldehyde, organic hydroperoxides and peroxyacyl nitrates that are all very reactive. This is a very fast reaction, generating more nitrogen oxides and organic nitrates. During these reactions more carcinogenic products are also formed. Hydrocarbons in polluted air show a high reactivity towards intermediate species such as peroxides. Nitrogen oxide emissions have become one of the greatest challenges in environment protection. For this reason, $\mathrm{NO}_{\mathrm{x}}$ emissions are controlled. In respect of the severe regulations imposed, car manufactures have had to decrease considerably the $\mathrm{NO}_{\mathrm{x}}$ emissions from their vehicles. This was achieved either through the action upon the nitrogen contents of the oil or by a modification of the engine's combustion chamber.

The conversion of nitrogen oxides is relatively easy. From a thermodynamic point of view, the molecule NO is unstable at lower temperatures. Accordingly, their catalytic decomposition into nitrogen and oxygen is feasible and expected to be one of the most efficient methods of removing them from exhaust gases.

An alternative is the selective catalytic reduction of NO. The SCR of NO by hydrocarbons is believed to be the most promising way to eliminate nitrogen oxide. The main advantage of the corresponding reaction is the use of gas mixture, very similar to that found in exhausts (Eq. 1).

$4 \mathrm{NO}+\mathrm{CH}_{4}=2 \mathrm{~N}_{2}+\mathrm{CO}_{2}+2 \mathrm{H}_{2} \mathrm{O}$

These processes opened new possibilities for the catalytic elimination of NO from exhaust gases, and the types of catalysts and the possible reductants are extremely varied.
In this paper, various noble metal-loaded aluminum oxides are examined for the selective catalytic reduction of NO by methane.

\section{EXPERIMENTAL}

All catalysts were prepared by the DIM method described in the literature ${ }^{4-8}$. The $\mathrm{Al}_{2} \mathrm{O}_{3}$ support obtained from Condea (Germany) with the initial total surface area $216.8 \mathrm{~m}^{2} / \mathrm{g}$ was sintered at $800^{\circ} \mathrm{C}$ for 6 hours in air. After that procedure the total surface area decreased to $86.2 \mathrm{~m}^{2} / \mathrm{g}$. That support was further used for the preparation of catalysts. In the first stage of the DIM process, $\mathrm{Al}_{2} \mathrm{O}_{3}$ support was immersed in a solution of $0.1 \mathrm{M}$ EDTA for 30 minutes at $70^{\circ} \mathrm{C}$. Then, the activated support was separated from the water phase and dried in air for 3 hours at $115^{\circ} \mathrm{C}$. The dried support samples activated with EDTA were immersed in an aqueous solution of suitable precursors. After such procedure the samples were separated from the aqueous phase, dried in air at $115^{\circ} \mathrm{C}$, and then calcined in air at $550^{\circ} \mathrm{C}$ for 1.5 hour. Metals contents in the pre-reduced samples were determined by the XRF method.

\section{Chemisorption of hydrogen and catalyst's characteriza- tion}

The obtained oxide precursors of platinum, palladium and rhodium catalysts were reduced in hydrogen at $500^{\circ} \mathrm{C}$ for 45 minutes, and then they were examined for hydrogen chemisorption in the static-volumetric apparatus ASAP $2010 \mathrm{C}$ at $110^{\circ} \mathrm{C}$ under hydrogen pressure $75-260 \mathrm{~mm}$ $\mathrm{Hg}$. The values of chemisorption were obtained using the extrapolation of isotherm to zero hydrogen pressure. An active surface area was calculated assuming chemisorption stoichiometry $\mathrm{Me}(\mathrm{Pt}, \mathrm{Rh}) / \mathrm{H}=1$ and $\mathrm{Pd} / \mathrm{CO}=1$, and the occupation of the area of $8.9 \mathrm{~A}^{2}$ by one hydrogen/ carbon oxide atom ${ }^{9-10}$. The main platinum, palladium and rhodium crystallite size was determined according to the equations given in paper ${ }^{11,12}$.

To characterize the catalysts, a specific BET surface area, and the chemical phase composition were determined. The specific BET surface area was measured by $\mathrm{N}_{2}$ adsorption using the ASAP 2010C instrument. The phase composition of the catalysts was determined with the XRF method (X-ray fluorescence) in the Department of Analitycal Laboratory, Faculty of Chemistry of UMCS. 


\section{Catalytic activity measurements}

The catalytic activity measurements were performed in a gradientless reactor based on the one described in ${ }^{\mathbf{1 3}}$. The feed gas mixture consisted of 1500 ppm NO, 4000 ppm $\mathrm{CH}_{4}$ and $\mathrm{He}$ was used in both cases as balance. The catalyst was pretreated in flowing helium at $500^{\circ} \mathrm{C}$ for 1 hour, whereas before the steady-state experiment was annealed in the reaction mixture and consecutive measurements were performed stepwise starting from 200 to $500^{\circ} \mathrm{C}$. All kinetic experiments were carried out in an atmosphere of helium, determining isothermally the relationship between the reaction rate of $\mathrm{NO}$ reduction and the degree of NO conversion (iso-X) ${ }^{\mathbf{1 4}}$. A TCD detector was used to follow the total concentration of hydrocarbon $\left(\mathrm{CH}_{4}\right)$, nitrogen oxide (NO) and the $\mathrm{N}_{2}$ formation over the tested catalysts. Temperature dependences of the reaction rate as a function of NO conversion has been measured (for the respective degree of the conversion $\mathrm{T}=$ const). From the functions of the reaction rate obtained from the degree of NO conversion at the given temperatures, the temperature dependence of the reaction rate at constant degree of NO conversion for various catalysts has been plotted.

\section{RESULTS AND DISCUSSION}

The contents of the active metal ( $\mathrm{Pt}, \mathrm{Pd}, \mathrm{Rh})$, dispersion and the calculated average metal particle sizes from hydrogen chemisorption experiments are summarized in Table 1.

The catalytic results at different temperatures for the examined catalysts are shown in Figs. $1-3$. A very different activity was observed for the various catalysts using.

The conversion to $\mathrm{N}_{2}$ is indicated in figures $4-6$.

The activity of the $\mathrm{Pd} / \mathrm{Al}$ as a function of temperature for the reduction with $\mathrm{CH} 4$ is shown in Fig. $1-6$. The total conversion of $\mathrm{NO}$ was achieved at $450^{\circ} \mathrm{C}$. The $\mathrm{Pt} / \mathrm{Al}$ catalyst starts to exhibit the activity at a temperature as low as $250^{\circ} \mathrm{C}$. The activity was high in the temperature range $350-500^{\circ} \mathrm{C}$ and the total conversion of $\mathrm{NO}$ was achieved at $400^{\circ} \mathrm{C}$. The $\mathrm{Rh} / \mathrm{Al}$ catalyst was very active in

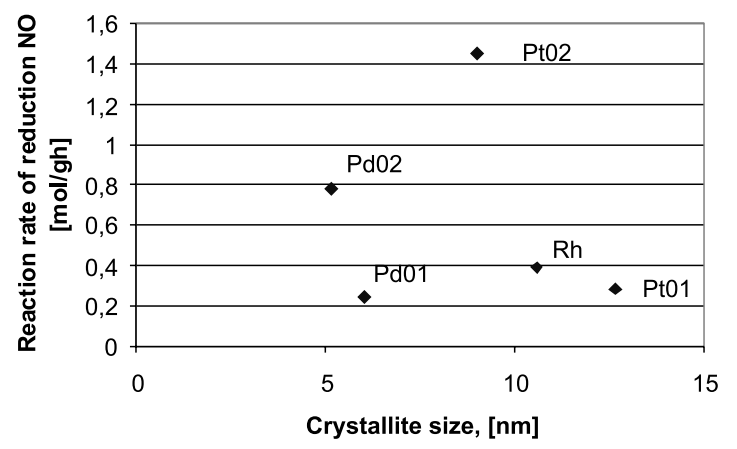

$500 \mathrm{C}$

Figure 1. The relationship between the rate of NO conversion and the crystallite size of metals in the examined catalysts at $500^{\circ} \mathrm{C}$

Table 1. The physico-chemical properties of the catalysts

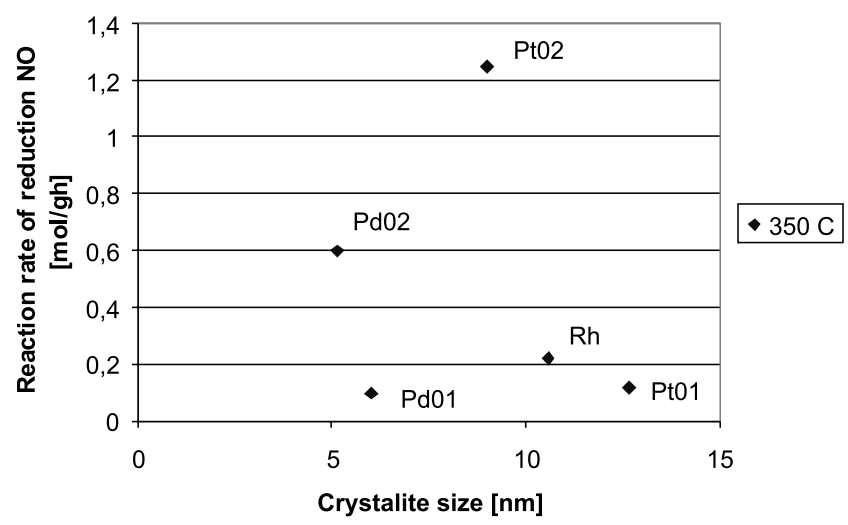

Figure 2. The relationship between the rate of NO conversion and the crystallite size of metals in the examined catalysts at $350^{\circ} \mathrm{C}$

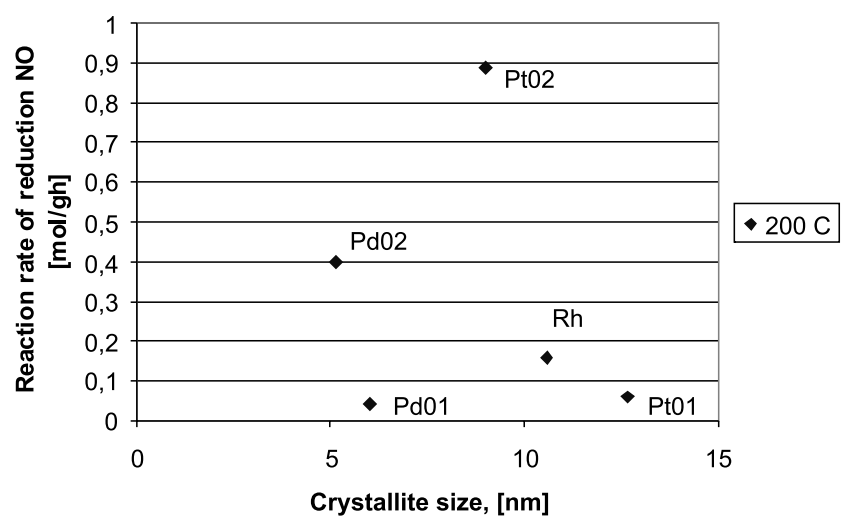

Figure 3. The relationship between the rate of NO conversion and the crystallite size of metals in the examined catalysts at $200^{\circ} \mathrm{C}$

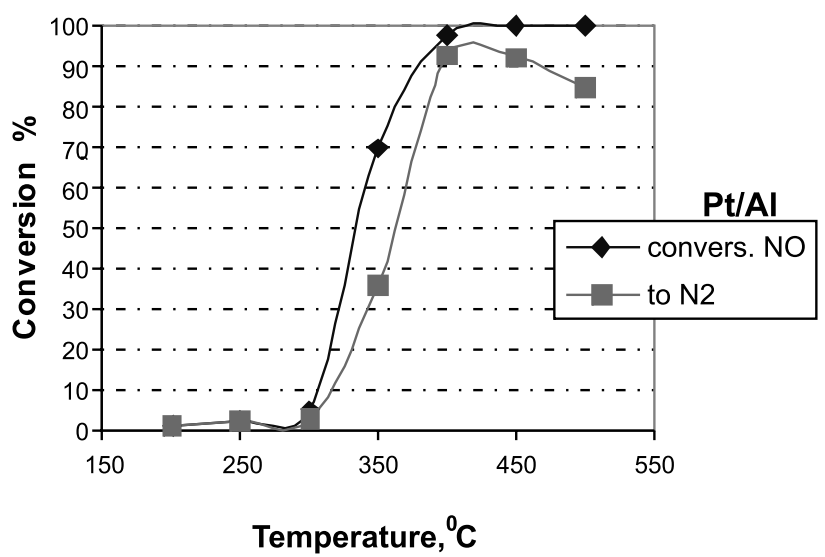

Figure 4. The conversion of $\mathrm{NO}$ to $\mathrm{N}_{2}$ for a $\mathrm{Pt} / \mathrm{Al}$ catalysts as a function for temperature

the $400-500^{\circ} \mathrm{C}$ region, to give the total conversion of $\mathrm{NO}$ at $450^{\circ} \mathrm{C}$. The reaction rate and the activities for the $\mathrm{NO} / \mathrm{CH}_{4}$ reaction increase with increasing the temperature. The tested catalysts have significantly different activities as shown in figures $1-3$. The specific activities for $\mathrm{N}_{2}$ production reflect this difference.

The $\mathrm{Rh} / \mathrm{Al}$ is significantly less active than the other two metals. Even in the more active state at high temperatures,

\begin{tabular}{|l|c|c|c|c|}
\hline Catalyst & Amount of active metal, $\%$ & \multicolumn{2}{|c|}{$\begin{array}{c}\text { Metal surface area }\left(\mathbf{m}^{2} / \mathbf{g}\right) \\
\text { active }\end{array}$} & Average metal partizle size, $\mathbf{n m}$ \\
\hline $\mathrm{Pt01} / \mathrm{Y}-\mathrm{Al}_{2} \mathrm{O}_{3}$ & 2,11 & 74,02 & 1,05 & 12,65 \\
\hline $\mathrm{Pt02} / \mathrm{Y}-\mathrm{Al}_{2} \mathrm{O}_{3}$ & 2,41 & 74,02 & 1,10 & 10,57 \\
\hline $\mathrm{Rh} / \mathrm{Y}-\mathrm{Al}_{2} \mathrm{O}_{3}$ & 0,76 & 71,6 & 4,06 & 9,00 \\
\hline $\mathrm{Pd0} 1 / \mathrm{Y}-\mathrm{Al}_{2} \mathrm{O}_{3}$ & 0,107 & 82,4 & 0,88 & 6,00 \\
\hline $\mathrm{Pd0} / \mathrm{Y}-\mathrm{Al}_{2} \mathrm{O}_{3}$ & 0,106 & 82,4 & 1,03 & 5,37 \\
\hline
\end{tabular}




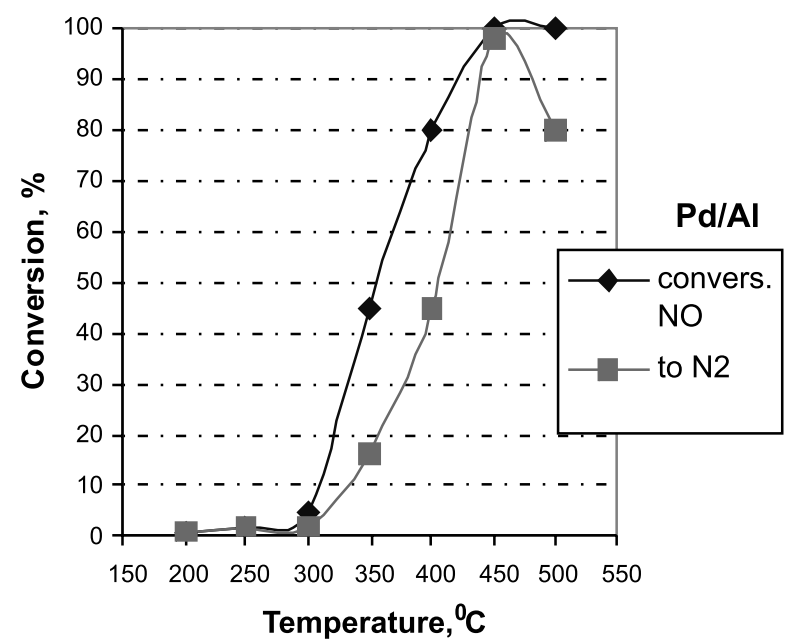

Figure 5. The conversion of $\mathrm{NO}$ to $\mathrm{N}_{2}$ for a $\mathrm{Pd} / \mathrm{Al}$ catalysts as a function for temperature

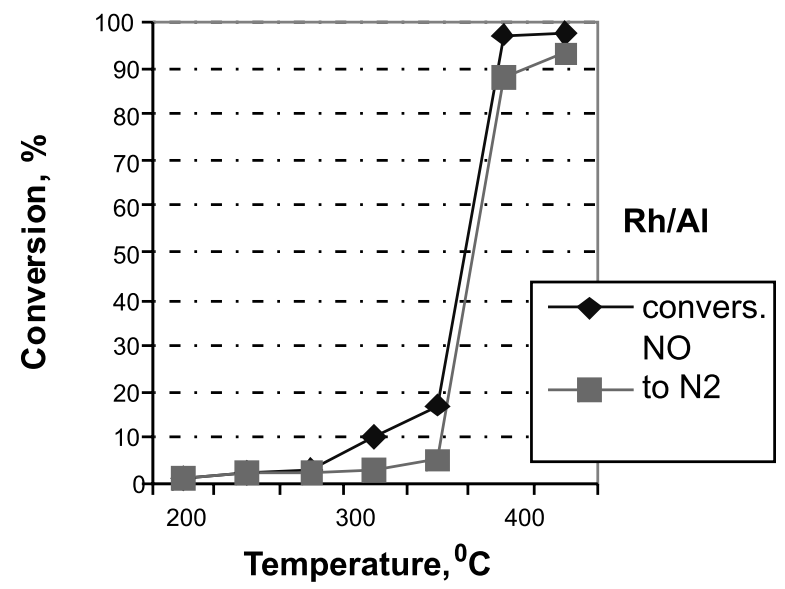

Figure 6. The conversion of $\mathrm{NO}$ to $\mathrm{N}_{2}$ for a $\mathrm{Rh} / \mathrm{Al}$ catalyst as a function for temperature

the $\mathrm{Rh}$ would have an activity comparable to that of $\mathrm{Pd}$ but lower than that of Pt. However, the Rh catalysts are very selective to $\mathrm{N}_{2}$ production. The selectivity of these catalysts to $\mathrm{N}_{2}$ maintained above $85 \%$ at temperature $350^{\circ} \mathrm{C}$. The order of the rate of NO reduction by methane follows the sequence: $\mathrm{Pt}>\mathrm{Pd}>\mathrm{Rh}$. Our results show that the specific activity for the reduction of $\mathrm{NO}$ to $\mathrm{N}_{2}$ by $\mathrm{CH}_{4}$ follows the sequence: $\mathrm{Pt}>\mathrm{Pd}>\mathrm{Rh}$. For all the catalysts the reduction of $\mathrm{NO}$ began between $200-250^{\circ} \mathrm{C}$. For higher temperatures, the extent of NO reduction decreased slightly. The maximum productions of $\mathrm{N}_{2}$ coincided and reached $90 \%$ with $\mathrm{Rh}, \mathrm{Pd}$ and $\mathrm{Pt}$ at temperatures in the interval $300-500^{\circ} \mathrm{C}$. Among the catalysts tested, Pt was the most active and selective in NO reduction. $\mathrm{N}_{2}$ production attained its maximum $(95 \%)$ at $450^{\circ} \mathrm{C}$ and decreased slightly to $85 \%$ at $500^{\circ} \mathrm{C}$. The Pt catalysts were more active and selective than Pd by about $40 \%$. It has been reported that, in the case of $\mathrm{Pt}$ catalysts, an increased $\mathrm{Pt}$ loading results in a decreased onset temperature of $\mathrm{NO}$ reduction ${ }^{15}$. As the metal loading is increased, the activity of the catalyst increases. The increase in the activity for NO reduction with increasing the $\mathrm{Pt}$ content is related to the particle size effect. Larger metal particles have higher turnover frequencies than the smaller ones. This behavior continues above $2 \%$ metal loading, as demonstrated by the present result.

\section{CONCLUSIONS}

The results reported in this paper have demonstrated that the activity of $\mathrm{Pt}, \mathrm{Pd}$ or $\mathrm{Rh}$ for the $\mathrm{NO} / \mathrm{CH}_{4}$ reaction follow the expected trend. We observe that $\mathrm{Pt}$ is the most active catalyst for the $\mathrm{NO} / \mathrm{CH}_{4}$ reaction, being an order more active than $\mathrm{Pd}$ and $\mathrm{Rh}$. It seems that the optimum choice of the catalyst for the removal of $\mathrm{NO}$ and $\mathrm{CH}_{4}$ will depend on the gas composition and the temperature.

The reduction of NO with methane is enjoying a lot of attention, but the hydrothermal stability with a sustained activity is still a troubling point for many current catalysts.

However, the catalytic reduction offers the cleanest and most direct approach to NO removal. For this approach another breakthrough is needed to provide a catalyst with substantial activity that can perform in the typical exhaust atmosphere.

\section{ACKNOWLEDGMENTS}

This work has been done within the framework of the grand sponsored by the Polish Committee for Science (project No.TB2-KBN-116/T09/2004/1C).

\section{LITERATURE CITED}

(1) Taylor K. C.: Nitric oxide catalysis in automotive exhaust systems, Cata. Rev.-Sci. Eng., 35 (1993) 457.

(2) Hodjati S., Vaezzadeh K., Petit C., Pitchon V.: NOx sorption-desorption study, Catal. Today 59 (2000) 323.

(3) Radojevic M.: Reduction of nitrogen oxides in flue gases, Environmental Pollution 102, S1 (1998) 685 - 689.

(4) Barcicki J., Nazimek D., Grzegorczyk W., Borowiecki T., Frąk R., Pielach M.: A new preparation technique of catalysts characterized by small metal crystallites, React. Kinet. Catal. Lett., 17 (1981)169.

(5) Ryczkowski J.: Modification of preparation technique for higly dispersed $\mathrm{Ni} / \gamma-\mathrm{Al}_{2} \mathrm{O}_{3}$ catalysts, React. Kinet. Catal. Lett., 40 (1989) 189.

(6) Ryczkowski J.: EDTA interaction with $\delta$-allumina. All NMR studies, Reeact. Kinet. Catal. Lett., 56 (1995) 241.

(7) Ryczkowski J., Borowiecki T., Naziemk D.: How modifiers can influence on the properties of $\mathrm{Ni} / \gamma-\mathrm{Al}_{2} \mathrm{O}_{3}$ catalysts, Adsorp. Sci. and Technol., 14 (1996) 113.

(8) Nazimek D., Ryczkowski J.: Conversion of n-butane over Pt-Me $/ \mathrm{Al}_{2} \mathrm{O}_{3}$ catalysts, Stud. Surf. Sci. and Catal., 119 (1998) 623.

(9) Yao H. C., Japar S., Schelef M.: Surface interactions in the system $\mathrm{Rh} / \mathrm{Al}_{2} \mathrm{O}_{3}$, J.Catal., 50 (1976) 407.

(10) Yao H. C., Schelef M.: J. Catal., 43 (1976) 393.

(11) Kobyliński T., Taylor K.: J. Catal., 43 (1974) 3764.

(12) Borodziński A., Bonarowska M.: Relation between crystallite size and dispersion on supported metal catalysts, Lamgmuir, 13 (1997) 5613.

(13) Nazimek D., Ryczkowski J.: A gradientless reactor for kinetic studies of catalytic processes, Ads.Sci.Technol., 17 (1999) 360.

(14) Barcicki J., Nazimek D., Grzegorczyk W., Borowiecki T., Denis A.: A new preparation technique of catalysts characterized by small metal crystallites, Polish Journal Chemistry 55 (1981) 1839.

(15) Burch R., Breen J. P., Meunier F. C.: A review of the selective reduction of $\mathrm{NO}_{\mathrm{x}}$ with hydrocarbons under learnburn conditions with non-zeolitic oxide and platinum group metal catalysts, App. Catal. 39 (2002) 283. 